D) Check for updates

Cite this as: $B M J 2021 ; 375: n 2726$ http://dx.doi.org/10.1136/bmj.n2726 Published: 08 November 2021

\section{India's army of unrecognised, unpaid female health workers}

This feature (BMJ 2021;375:n2509, doi:, 22 October 2021) stated that over 70 ooo ASHAs across Maharashtra went on indefinite strike on 15 June 2020. The strike was on 15 June 2021, and the article has been corrected. 